\title{
The Reliability and Validity of Korean Pediatric Functional Muscle Testing in Children with Motor Disorder
}

Hye-Jung Seo ${ }^{1}$, Joong-Hwi Kim²

'Department of Physical Therapy, Bobath Children's Hospital, Seongnam; ²Department of Physical Therapy, College of Bio and Medical Sciences, Catholic University of Daegu, Daegu, Korea

Purpose: This study was conducted to develop a Korean version of the pediatric functional muscle test (K-PFMT) for children with motor developmental disorders, and to verify its reliability and validity.

Methods: The subjects were 40 children, aged below 5 years. Each was scored on the K-PFMT by 14 physical therapists to determine inter-rater reliability and internal consistency. Additionally, 3 of the 14 therapists tested 20 children again one or two weeks later to determine test-retest reliability. The internal consistency was calculated by Cronbach's alpha. The inter-rater and test-retest reliability were calculated using the intraclass correlation coefficient (ICC). One-way ANOVA and the paired t-test were used to compare differences among the three evaluator groups and between the test and retest group. Concurrent validity was evaluated by Pearson's correlation with a total score of GMFM.

Results: Chronbach's alpha was over 0.98 for each test item and 0.99 for the total items. There was no significant differences in the score of K-PFMT among the three evaluator groups except for a few items. The test-retest ICC was from 0.89 to 1.00 and from 0.82 to 1.00 , respectively. There was no significant difference between the test and retest group, except for a few items. There were high significant correlations between K-PFMT and GMFM.

Conclusion: This study showed that a K-PFMT with relatively high reliability and validity was successfully developed. The K-PFMT will be a useful tool for measurement of muscle strength of children with motor developmental disorder.

Keywords: Reliability, Validity, Pediatric functional muscle testing, Motor disorder

\section{서 론}

영유아기에 있어서 장애의 발생은 장애 아동의 삶에 평생 동안 영향 을 미친다는 점에서 매우 중요하며, 영유아기 조기진단 및 조기치료 가 장애의 진전과 장애의 발생을 방지할 수 있으므로 무엇보다 중요 하다. 조기진단을 위해 국내 소아 물리치료분야에서는 서구의 최신 이론과 치료방법들이 많이 소개되고 있지만, 물리치료사가 사용하 는 표준화 검사도구의 사용이 극히 적고, 연구가 거의 되어 있지 않는 실정이다.,3 또한 대다수의 치료사들이 사용하고 있는 운동평가는 운동발달단계이며, 수치화되고 정형화된 평가도구의 사용이 적고, 신뢰도나 타당도가 검증되지 않은 외국의 평가도구를 그대로 번역하 여 사용하고 있는 실정이다. ${ }^{4}$

일반적으로 발달 장애가 있는 아동을 대상으로 하는 물리치료에
서 사용되는 평가도구는 그 종류가 제한적이며, 주관적 서술에 많이 의존하고 있다. ${ }^{2}$ Park 등은 이렇게 평가도구의 사용률이 낮은 원인 중 하나는 평가도구를 이용하여 평가하더라도 의료보험료를 청구할 수 없는 현행 의료보험수가체계의 문제라고 하였다. 특히 현행 의료 보험수가체계에서 소아 물리치료사가 시행하는 평가는 신경학적 척 도검사, 도수근력검사, 관절가동범위검사 등으로 이 중 도수근력검사 의 사용은 매우 저조한 것으로 나타났다. ${ }^{2}$ 이는 기존의 도수근력검사 방법으로는 발달지연 및 뇌성마비 아동의 근력을 평가하는 것이 부 적합하여 사용률이 저조했던 것으로 사료된다. 이를 개선하기 위해 서는 5 세 미만의 아동이나 의사소통에 어려움이 있는 아동에게도 적용 가능한 소아용 기능근력검사 개발 및 보급이 절실히 요구된다.

이에 본 연구는 선행연구를 통하여 2006년에 국내에서 번역된 근 력 및 감각 검사 라는 책의 6 장에서 소개된 바 있는 Venita ${ }^{5}$ 에 의해 개
Received Jul 11, 2016 Revised Aug 3, 2016

Accepted Aug 23, 2016

Corresponding author Joong-Hwi Kim

E-mail charmpt@cu.ac.kr
Copylight (C) 2016 The Korea Society of Physical Therapy

This is an Open Access article distribute under the terms of the Creative Commons Attribution Non-commercial License (Http:// creativecommons.org/license/by-nc/4.O.) which permits unrestricted non-commercial use, distribution, and reproduction in any medium, provided the original work is properly cited. 
발된 소아용 기능근력검사를 국내에 보급하기 위한 중요한 근거를 마련하기 위해, 우리나라의 문화에 맞게 문항을 수정하는 등 전문가 의 의견을 수렴하는 1 차 및 2 차 내용타당도 검증을 통하여 머리 움직 임 3항목, 체간 움직임 5항목, 상지 움직임 4항목, 하지 움직임 3항목 으로, 총 4 가지 영역에서 15 개 항목으로 구성된 한국형 소아 기능근 력검사를 개발하였다. ${ }^{6}$

따라서 본 연구는 새롭게 개발된 한국형 소아 기능근력검사가 임 상적으로 5 세 미만의 운동발달에 문제가 있는 아동의 근력검사를 위 한 검사도구로 적절한지에 알아보기 위하여 신뢰도 및 타당도를 알 아보고자 하였으며, 이를 통하여 임상에서 사용하기 위한 기초 자료 를 마련하기 위한 토대로 실시되었다.

\section{연구 방법}

\section{1. 연구 대상}

본 연구는 2015년 9월부터 10 월까지 경기도 소재 $\bigcirc \bigcirc \circ$ 어린이의원 에서 외래 및 입원을 통해 재활치료를 받는 발달지연 아동 20 명과 뇌 성마비 아동 20 명, 총 40 명을 대상으로 하였다. 최근 6 개월 이내에 수 술, 또는 시술을 하지 않은 아동으로 선정하였으며, 정형외과적인 문 제로 움직임에 문제가 있거나, 의사소통 기능 분류 체계에서 타인과 의 의사소총이 원활한 1 수준의 아동은 연구 대상에서 제외하였다. 먼저 연구 목적과 방법에 대해 충분히 설명하고 보호자와 대상 아동 의 연구 참여 동의 하에 동의서를 받은 후 비디오 촬영을 실시하였다.

\section{2. 연구도구}

\section{1) 한국형 소아 기능근력검사}

국내에서 2006년에 번역되어 소개된 Venita L.C.에 의해 개발된 소아 용 기능근력검사는 출생에서 생후 6-7개월 사이의 아동은 발달 반사 를 사용하여 반응을 보았고, 생후 6-7개월에서 1 세까지의 아동은 중 력을 고려하지 않고 자발적인 움직임을 자극함으로써 그리고 1세에 서 5 세 사이의 아동은 중력에 대한 자발적 움직임을 자극함으로써 평가하도록 고안되었다. 국내에 보급하기 위한 근거를 마련하기 위해 본 연구자는 전문가의 1 차 및 2 차 내용타당도 검증을 통하여 우리나 라의 문화에 맞게 문항을 수정하여 머리 움직임 3항목, 체간 움직임 5 항목, 상지 움직임 4항목, 하지 움직임 3항목으로, 총 4 가지 영역에서 15 개 항목으로 구성된 한국형 소아 기능근력검사를 개발하였다(Appendix). 각 항목은 우선 아동의 자발적 움직임에 따른 발달단계 개월 별로 1 개의 해당 란에 ' $\sqrt{ }$ ' 표기를 하고, 해당 개월에서 아동의 움직임 을 평가하여 기존의 도수근력검사의 등급 척도와 같이 0-5등급으로 총 6 등급으로 구분되었다. 0 등급(Zero)은 시진이나 촉진 시 근육의 수축이 없는 경우, 1 등급(Trace)은 약간의 근 수축이 있으나 움직임은
없는 상태, 2 등급(Poor)은 일부의 관절가동범위에서 움직일 수 있는 경우, 3 등급(Fair)은 중력에 저항하여 전 관절가동범위를 움직일 수 있는 경우와 개월 차이에 따른 움직임을 완전히 수행할 수 있는 경우, 4 등급(Good)은 중력에 저항하여 전 관절가동범위를 움직이고, 중간 정도의 저항에 대항할 수 있는 경우, 마지막으로 5 등급(Normal)은 중 력에 저항하여 전 관절가동범위를 움직이고, 최대 저항에 대항할 수 있는 경우로 각 등급의 정의가 기존의 도수근력검사와는 약간의 차 이가 있다.

\section{3. 연구방법}

1) 측정절차

연구의 선정 기준에 부합한 대상자들의 보호자와의 면담을 통하여 성별, 연령, 진단명 등 일반의학적인 특성을 수집하였고, 대동작 기능, 손의 기능, 의사소통 능력 등은 연구자가 직접 아동을 대상으로 측정 하였다. 대동작 기능은 대동작 기능 분류 체계를 사용하였으며, 손의 기능은 손기능 분류 체계, 의사소통 능력은 의사소통 기능 분류 체계 를 사용하여 측정하였다.

2 명의 연구자가 캠코더를 이용하여 한국형 소아 기능근력검사를 평가하기 위한 과제를 연구대상자들이 수행하는 모습을 비디오로 촬영하였다. 검사자간 신뢰도를 측정하기 위하여 촬영에 참여한 연 구자를 포함하여 14 명의 평가자가 비디오를 보면서 점수를 측정하였 다. ${ }^{78}$ 또한 검사-재검사 신뢰도를 측정하기 위해서는 경력 차이에 따 른 세 군에서 한 명씩 무작위로 선별하여 1 차 평가를 실시한 후, 40 명 의 아동 중 무작위 표본추출하여 선별된 20 명을 1-2주 간격으로 동일 한 치료사가 동일한 비디오를 보고 재평가하였다. 3.78 이것은 아동의 수행 시 시간이나 환경 등 동일한 조건을 제공하기 위해서, 기억효과 와 반복효과를 통제하기 위해서이다. ${ }^{3}$

한국형 소아 기능근력검사의 타당도를 조사하기 위해 대동작 기 능 평가(GMFM-66)를 이용하여 대상자들을 평가하였다. 평가는 일 주일 안에 이루어지도록 하였다. ${ }^{9}$

총 연구는 2015년 9월에서 10월까지 2개월간 진행되었다. 본격적인 연구에 앞서 대구가톨릭대학교 생명윤리위원에서 승인을 받은 후 모 든 연구가 진행되었다(승인번호: CUIRB-2015-0031).

\section{2) 검사자 선정}

한국형 소아 기능근력검사의 내적일치도와 검사-재검사 및 검사자 간 신뢰도를 알아보기 위하여 경기도 소재 $\bigcirc \bigcirc \circ$ 어린이의원에서 근 무하고 있는 물리치료사 중에 치료 경력의 차이에 따라 2-4년의 경력 5 명, 5-9년 5명, 10 년 이상 4 명으로 총 14 명의 치료사를 선정하여 세 군 으로 분류하였다. 14 명의 치료사 중 남자는 5 명, 여자는 9 명이었으며, 평균 연령은 2-4년 경력군은 25.0세, 5-9년은 30.6세, 10년 이상은 37.3 
세였다. 경력 평균은 2-4년군에서는 2.4년, 5-9년은 7.2년, 10 년 이상은 15.0년이었다.

\section{3) 검사자 훈련 과정}

검사자 훈련 과정은 검사에 대한 내용을 충분히 숙지하여 오염변인 을 최소화하기 위해서, 검사 전에 한국형 소아 기능근력검사의 매뉴 얼을 가지고 평가에 참여할 치료사들에게 평가방법과 평가 시 숙지 해야 할 사항에 대하여 오리엔테이션을 실시하였고, ${ }^{3}$ 새로운 한국형 소아 기능근력검사를 습득할 수 있도록 3 일 이상 훈련하여 숙지시켰 다. ${ }^{10}$ 모든 평가자는 비디오 파일을 평가하기 전에 비디오 훈련을 2회 실시하였으며, ${ }^{3}$ 모의 평가 1 회를 실시하여 검사도구의 세부 항목과 점수 평가기준에 대해 충분히 논의하였다?

\section{3. 자료 분석}

자료 분석을 위해 개월 항목은 0-3개월을 1, 4-6개월을 2, 7-9개월을 3, $10-12$ 개월을 4,12 개월을 5 로 개월이 높아지면 높은 점수를 부여하여 코딩하여 입력하였으며, 움직임의 근력평가는 0-5로 단계별로 코딩하 여 입력하였다. 모든 통계 자료의 처리에는 SPSS version 19.0을 사용하 였으며, 통계학적 유의 수준 $(\alpha)$ 을 0.05 이하로 하여 검정하였다.

대상자들의 일반적인 특성은 빈도분석을 하였으며, 내적 일치도를 알아보기 위해서는 크론바 알파(Cronbach's alpha) 값을 이용하였다. 검사자간 신뢰도는 동일한 아동을 대상으로 경력이 다른 세 군이 측 정한 점수에 대한 차이를 알아보기 위하여 일원배치분석 기법(Oneway analysis)을 사용하였고, 사후 검증으로 본페로니(Bonferroni) 수 정법을 이용하여 각 변인의 변화를 비교하였다. 신뢰도 계수는 급간 내 상관계수(intraclass correlation coefficients, ICCs)를 구하였다.
검사-재검사 신뢰도는 1-2주 간격으로 측정한 평가 점수의 차이를 알아보기 위하여 Paired t-test를 하였고, 두 검사의 신뢰도를 알아보 기 위해서는 급간 내 상관계수를 이용하였다.

타당성을 인정받고 있는 기존의 평가도구인 GMFM-66과의 상관 관계를 비교하기 위하여 Pearson 상관계수(Pearson correlation coefficient)를 활용하여 공인타당도를 알아보았다. 뇌성마비 20명, 발달지 연 20명, 총 40명의 연구대상자를 대상으로 GMFM-66의 총점을 구하 였으며, 한국형 소아 기능근력검사의 경우 각 항목에서 개월평가와 근력평가 2가지를 평가하도록 구성되어 있어서, GMFM과의 상관 분 석을 위해서 불가피하게 개월평가와 근력평가를 동시에 고려하여 등 급을 재설정하였다. 0-3개월의 Zero 등급은 '0', 0-3개월의 Trace는 '1', 0-3개월의 Poor는 '2', 0-3개월의 Fair는 '3', 4-6개월의 Poor는 '4', 4-6개월 의 Fair는 '5', 4-6개월의 Good은 '6, 7-9개월의 Poor는 '6, 7-9개월의 Fair 는 '7', 7-9개월의 Good은 '8', 10-12개월의 Poor는 ' 8', 10-12개월의 Fair는 '9', 10-12개월의 Good은 '10', 12개월의 Poor는 '10', 12개월의 Fair는 '11', 12 개월의 Good은 ' 12 '로 등급을 재설정하였다.

\section{연구 결과}

\section{1. 연구대상자의 특성}

본 연구에 참여한 대상자는 발달지연 아동 20 명, 뇌성마비 아동 20 명, 총 40 명이었다. 발달지연 아동의 경우, 다운 증후군이 3 명, 레트 증후군 이 1 명, 엔젤만 증후군이 1 명이었으며, 나머지 15 명은 단순발달지연으로 진단받은아동이었다. 연구 대상자의 일반적인 특성은 Table 1과같다.

Table 1. General characteristics of the subjects $(n=40)$

\begin{tabular}{|c|c|c|c|c|c|}
\hline \multirow{2}{*}{ Variables } & \multirow{2}{*}{ Category } & \multicolumn{2}{|c|}{ DD group $(n=20)$} & \multicolumn{2}{|c|}{ CP group $(n=20)$} \\
\hline & & Frequency & Mean $\pm S D$ & Frequency & Mean $\pm S D$ \\
\hline \multirow[t]{2}{*}{ Gender } & Male & $11(55 \%)$ & & $12(60 \%)$ & \\
\hline & Female & $9(45 \%)$ & & $8(40 \%)$ & \\
\hline Age (y) & $1 / 2 / 3 / 4 / 5(y)$ & $1 / 12 / 4 / 3 / 0$ & $2.45 \pm 0.83$ & $0 / 9 / 3 / 5 / 3$ & $3.10 \pm 1.17$ \\
\hline \multirow[t]{3}{*}{ Distribution of $C P$} & Quardriplegia & - & & $9(45 \%)$ & \\
\hline & Diplegia & - & & $9(45 \%)$ & \\
\hline & Hemiplegia & - & & $2(10 \%)$ & \\
\hline \multirow[t]{4}{*}{ Type of CP } & Spastic bilateral & - & & $16(80 \%)$ & \\
\hline & Spastic unilateral & - & & $2(10 \%)$ & \\
\hline & Athetosis & - & & $1(5 \%)$ & \\
\hline & Ataxia & - & & $1(5 \%)$ & \\
\hline GMFCS & I/II/III/IVN & $2 / 7 / 8 / 3 / 0$ & $2.60 \pm 0.88$ & $3 / 7 / 2 / 2 / 6$ & $3.05 \pm 1.54$ \\
\hline MACS & I/II/III/IVN & $0 / 5 / 4 / 11 / 0$ & $3.25 \pm 0.85$ & $0 / 6 / 4 / 3 / 7$ & $3.55 \pm 1.28$ \\
\hline CFCS & I/II/III/IVN & $0 / 1 / 6 / 10 / 3$ & $3.75 \pm 0.79$ & $0 / 4 / 5 / 3 / 5$ & $3.30 \pm 1.22$ \\
\hline
\end{tabular}

DD: Developmental delay, CP: Cerebral palsy, GMFCS: Gross motor functional classification system, MACS: Manual ability classification system, CFCS: Communication functional classification system. 


\section{2. 한국형 소아기능근력검사의 내적일치도 신뢰도 검증결과}

한국형 소아 기능근력검사의 내적 일치도 신뢰도는 뇌성마비 20 명, 발달지연 20 명, 총 40 명의 연구대상자로 14 명의 검사자가 한국형 소 아 기능근력검사지로 평가한 결과를 이용하여 검증하였다. 내적 일 치도 분석을 위하여 크론바 알파 값을 측정한 결과, 15 개 평가 항목 에서 각각 0.98 에서 0.99 로 모두 높게 나타났으며, 15 가지 항목 전체의 내적 일치도는 0.98 로 매우 높게 나타났다.

\section{3. 한국형 소아 기능근력검사의 검사자간 신뢰도 검증 결과}

한국형 소아 기능근력검사의 검사자간 신뢰도 분석을 위하여 뇌성 마비 아동군과 발달지연 아동군의 두 군으로 구별하여 급간 내 상관 계수를 분석한 결과, 뇌성마비 아동군에서 2-4년 경력의 검사자는 개 월평가에서 0.90 에서 1.00 으로 분포하였으며, 각 항목의 근력평가는
0.65에서 0.96으로 분포하였다. 5-9년 경력의 검사자는 개월평가에서 0.90 에서 1.00 으로 분포하였으며, 각 항목의 근력평가는 0.81 에서 0.98 로 분포하였다. 10 년 이상의 검사자는 개월평가에서 0.89 에서 0.99 로 분포하였으며, 각 항목의 근력평가에서는 0.82 에서 1.00 으로 분포하 였다. 14 명 전체의 경우는 개월평가에서는 0.91 에서 1.00 으로 분포하 였으며, 각 항목의 근력평가는 0.77 에서 0.96 으로 분포하였다. 발달지 연 아동군에서 2-4년 경력의 검사자는 개월평가에서 0.75 에서 1.00 으 로 분포하였으며, 각 항목의 근력평가는 0.46 에서 0.93 으로 분포하였 다. 5-9년 경력의 검사자는 개월평가에서 0.71 에서 1.00 으로 분포하였 으며, 각 항목의 근력평가는 0.64 에서 0.96 로 분포하였다. 10 년 이상의 검사자는 개월평가에서 0.88 에서 1.00 으로 분포하였으며, 각 항목의 근력평가에서는 0.87 에서 0.98 로 분포하였다. 14 명 전체의 경우는 개 월평가에서는 0.71 에서 1.00 으로 분포하였으며, 각 항목의 근력평가

Table 2. Mean comparison of month score \& muscle strength score of three groups in children with cerebral palsy

\begin{tabular}{|c|c|c|c|c|c|c|}
\hline \multirow{2}{*}{$\begin{array}{l}\text { Items } \\
\text { Position }\end{array}$} & & \multirow{2}{*}{$\frac{2-4 y}{\text { Mean } \pm S D}$} & \multirow{2}{*}{$\frac{5-9 y}{\text { Mean } \pm S D}$} & \multirow{2}{*}{$\frac{10 y^{-}}{\text {Mean } \pm S D}$} & \multirow{2}{*}{$\mathrm{F}$} & \multirow{2}{*}{$p$} \\
\hline & & & & & & \\
\hline Neck extension & Month & $1.84 \pm 0.55$ & $1.78 \pm 0.03$ & $1.88 \pm 0.05$ & 5.15 & $0.03^{*}$ \\
\hline Prone & Muscle strength & $2.41 \pm 0.02$ & $2.30 \pm 0.05$ & $2.39 \pm 0.06$ & 8.98 & $0.00^{*}$ \\
\hline Neck extension & Month & $1.70 \pm 0.00$ & $1.70 \pm 0.00$ & $1.70 \pm 0.00$ & 0.00 & 1.00 \\
\hline Horizontal suspension & Muscle strength & $2.85 \pm 0.04$ & $2.71 \pm 0.16$ & $2.66 \pm 0.03$ & 3.83 & 0.05 \\
\hline Neck flexion & Month & $2.15 \pm 0.13$ & $2.18 \pm 0.03$ & $2.26 \pm 0.03$ & 2.16 & 0.16 \\
\hline Pull to sit/Supine & Muscle strength & $2.48 \pm 0.08$ & $2.48 \pm 0.07$ & $2.54 \pm 0.06$ & 1.01 & 0.39 \\
\hline Trunk flexion (upper) & Month & $2.13 \pm 0.03$ & $2.04 \pm 0.04$ & $2.10 \pm 0.10$ & 2.87 & 0.10 \\
\hline Pull to sit & Muscle strength & $2.80 \pm 0.09$ & $2.46 \pm 0.09$ & $2.51 \pm 0.03$ & 0.64 & 0.55 \\
\hline Trunk flexion (lower) & Month & $1.84 \pm 0.05$ & $1.78 \pm 0.03$ & $1.88 \pm 0.05$ & 5.15 & $0.03^{*}$ \\
\hline Supine & Muscle strength & $2.41 \pm 0.02$ & $2.31 \pm 0.05$ & $2.34 \pm 0.05$ & 8.98 & $0.00^{*}$ \\
\hline Trunk extension & Month & $1.50 \pm 0.04$ & $1.52 \pm 0.03$ & $1.50 \pm 0.00$ & 0.88 & 0.44 \\
\hline Horizontal suspension & Muscle strength & $2.40 \pm 0.11$ & $2.29 \pm 0.07$ & $2.30 \pm 0.04$ & 2.87 & 0.10 \\
\hline Trunk flexion \& extension & Month & $1.49 \pm 0.08$ & $1.48 \pm 0.03$ & $1.49 \pm 0.05$ & 0.05 & 0.96 \\
\hline Sitting & Muscle strength & $2.14 \pm 0.07$ & $2.10 \pm 0.05$ & $2.09 \pm 0.03$ & 1.26 & 0.32 \\
\hline Trunk rotation & Month & $2.18 \pm 0.03$ & $2.19 \pm 0.02$ & $2.20 \pm 0.00$ & 0.98 & 0.41 \\
\hline Supine/Sitting & Muscle strength & $2.46 \pm 0.04$ & $2.47 \pm 0.06$ & $2.41 \pm 0.20$ & 1.45 & 0.27 \\
\hline Shoulder flexion & Month & $1.65 \pm 0.00$ & $1.66 \pm 0.02$ & $1.65 \pm 0.00$ & 0.88 & 0.44 \\
\hline Supine & Muscle strength & $2.74 \pm 0.04$ & $2.65 \pm 0.05$ & $2.70 \pm 0.00$ & 6.09 & $0.02^{*}$ \\
\hline Shoulder flexion & Month & $1.52 \pm 0.03$ & $1.52 \pm 0.03$ & $1.50 \pm 0.00$ & 1.05 & 0.38 \\
\hline Sitting & Muscle strength & $2.38 \pm 0.08$ & $2.28 \pm 0.05$ & $2.36 \pm 0.03$ & 4.04 & 0.05 \\
\hline Elbow extension & Month & $1.65 \pm 0.00$ & $1.66 \pm 0.02$ & $1.65 \pm 0.00$ & 0.88 & 0.44 \\
\hline Supine & Muscle strength & $2.90 \pm 0.04$ & $2.93 \pm 0.08$ & $2.99 \pm 0.03$ & 2.56 & 0.12 \\
\hline Elbow extension & Month & $1.65 \pm 0.00$ & $1.65 \pm 0.00$ & $1.65 \pm 0.00$ & 0.00 & 1.00 \\
\hline Prone & Muscle strength & $2.90 \pm 0.04$ & $2.89 \pm 0.04$ & $2.95 \pm 0.07$ & 2.00 & 0.18 \\
\hline Hip \& knee flexion & Month & $1.55 \pm 0.00$ & $1.55 \pm 0.00$ & $1.55 \pm 0.00$ & 0.00 & 1.00 \\
\hline Supine & Muscle strength & $2.39 \pm 0.07$ & $2.35 \pm 0.09$ & $2.35 \pm 0.04$ & 0.48 & 0.63 \\
\hline Hip \& knee flexion & Month & $3.01 \pm 0.22$ & $3.00 \pm 0.00$ & $3.00 \pm 0.00$ & 0.88 & 0.44 \\
\hline Prone & Muscle strength & $2.17 \pm 0.03$ & $2.18 \pm 0.03$ & $2.16 \pm 0.03$ & 0.82 & 0.49 \\
\hline Hip \& knee extension & Month & $2.52 \pm 0.07$ & $2.53 \pm 0.03$ & $2.51 \pm 0.03$ & 0.17 & 0.85 \\
\hline Supported and independent standing & Muscle strength & $2.39 \pm 0.07$ & $2.33 \pm 0.07$ & $2.43 \pm 0.03$ & 3.62 & 0.06 \\
\hline
\end{tabular}

${ }^{*} p<0.05$. 
는 0.67 에서 0.95 로 분포하였다.

경력 차이에 따른 검사자간 신뢰도를 비교하기 위하여 경력 차이 에 따른 검사자군 별로 평가 항목별 평균점수를 구하여 일원배치분 석으로 비교하였다. 뇌성마비 아동군의 개월평가에서는 경부 신전의 엎드린 자세 항목과 하부 체간 굴곡 항목에서 검사자군 간 차이가 있 었으나 $(\mathrm{p}<0.05)$, 나머지 13 항목에서는 검사자군 간 차이가 없었다 ( $p>0.05$ ) (Table 2). 각 항목의 근력평가에서는 경부신전의 엎드린 자 세 항목, 하부 체간 굴곡 항목, 견관절 굴곡의 바로 누운 자세 항목에 서 검사자군 간 차이가 있었으나 $(\mathrm{p}<0.05)$, 나머지 12 항목에서는 검사 자군 간 차이는 없었다 $(\mathrm{p}>0.05)$ (Table 2).

발달지연 아동군의 개월평가에서는 하부 체간 굴곡과 체간 신전 항목에서 검사자군 간 차이가 있었으며 $(\mathrm{p}<0.05)$, 각 항목의 근력평가 에서는 경부 굴곡과 고관절과 슬관절 굴곡의 엎드린 자세 항목에서
검사자군 간 차이가 있었다 $(\mathrm{p}<0.05)$ (Table 3).

\section{4. 한국형 소아 기능근력검사의 검사-재검사 신뢰도 검증 결과}

한국형 소아 기능근력검사의 검사-재검사 신뢰도 분석을 위하여 급 간 내 상관계수를 분석한 결과, 2-4년 경력의 A 검사자는 개월평가에 서 0.90 에서 1.00 으로 분포하였으며, 각 항목의 근력평가는 0.83 에서 1.00 으로 분포하였다. 5-9년 경력의 B 검사자는 개월평가에서 0.89 에서 1.00 으로 분포하였으며, 각 항목의 근력평가는 0.88 에서 0.98 로 분포하 였다. 10 년 이상의 C 검사자는 개월평가에서 0.90 에서 1.00 으로 분포하 였으며, 각항목의 근력평가에서는 0.82 에서 1.00 으로 분포하였다.

1 차 검사와 2 차 검사의 평가 점수의 차이를 알아보기 Paired t-test 를 분석한 결과, $2-4$ 년 경력의 A 검사자와 10 년 이상의 C 검사자는 1 차 검사와 2 차 검사에서 개월평가 및 근력평가 15 항목 모두에서 통계

Table 3. Mean comparison of month score \& muscle strength score of three groups in children with developmental delay

\begin{tabular}{|c|c|c|c|c|c|c|}
\hline \multirow{2}{*}{$\begin{array}{l}\text { Items } \\
\text { Position }\end{array}$} & & \multirow{2}{*}{$\frac{2-4 y}{\text { Mean } \pm S D}$} & \multirow{2}{*}{$\frac{5-9 y}{\text { Mean } \pm S D}$} & \multirow{2}{*}{$\frac{10 y^{-}}{M e a n \pm S D}$} & \multirow{2}{*}{$\mathrm{F}$} & \multirow{2}{*}{$\mathrm{p}$} \\
\hline & & & & & & \\
\hline Neck extension & Month & $1.95 \pm 0.00$ & $1.95 \pm 0.00$ & $1.95 \pm 0.00$ & 0.00 & 1.00 \\
\hline Prone & Muscle strength & $3.06 \pm 0.12$ & $3.05 \pm 0.05$ & $3.01 \pm 0.08$ & 0.36 & 0.71 \\
\hline Neck extension & Month & $1.95 \pm 0.00$ & $1.95 \pm 0.00$ & $1.95 \pm 0.00$ & 0.00 & 1.00 \\
\hline Horizontal suspension & Muscle strength & $3.06 \pm 0.12$ & $3.05 \pm 0.05$ & $3.01 \pm 0.08$ & 0.36 & 0.71 \\
\hline Neck flexion & Month & $2.15 \pm 0.04$ & $2.13 \pm 0.03$ & $2.13 \pm 0.03$ & 0.86 & 0.45 \\
\hline Pull to sit/Supine & Muscle strength & $2.66 \pm 0.07$ & $2.84 \pm 0.11$ & $2.78 \pm 0.05$ & 6.37 & $0.02^{*}$ \\
\hline Trunk flexion (upper) & Month & $2.26 \pm 0.03$ & $2.24 \pm 0.03$ & $2.24 \pm 0.03$ & 1.35 & 0.30 \\
\hline Pull to sit & Muscle strength & $2.65 \pm 0.14$ & $2.70 \pm 0.07$ & $2.64 \pm 0.11$ & 0.41 & 0.67 \\
\hline Trunk flexion (lower) & Month & $2.37 \pm 0.06$ & $2.29 \pm 0.02$ & $2.31 \pm 0.03$ & 5.50 & $0.02^{*}$ \\
\hline Supine & Muscle strength & $2.74 \pm 0.11$ & $2.79 \pm 0.05$ & $2.76 \pm 0.03$ & 0.57 & 0.58 \\
\hline Trunk extension & Month & $1.65 \pm 0.04$ & $1.70 \pm 0.04$ & $1.64 \pm 0.03$ & 4.76 & $0.03^{*}$ \\
\hline Horizontal suspension & Muscle strength & $2.63 \pm 0.08$ & $2.64 \pm 0.07$ & $2.64 \pm 0.05$ & 0.03 & 0.97 \\
\hline Trunk flexion \& extension & Month & $1.55 \pm 0.00$ & $1.55 \pm 0.00$ & $1.55 \pm 0.00$ & 0.00 & 1.00 \\
\hline Sitting & Muscle strength & $2.37 \pm 0.11$ & $2.38 \pm 0.03$ & $2.41 \pm 0.03$ & 0.44 & 0.65 \\
\hline Trunk rotation & Month & $2.36 \pm 0.02$ & $2.35 \pm 0.00$ & $2.35 \pm 0.00$ & 0.88 & 0.44 \\
\hline Supine/Sitting & Muscle strength & $2.64 \pm 0.04$ & $2.68 \pm 0.06$ & $2.61 \pm 0.03$ & 2.63 & 0.12 \\
\hline Shoulder flexion & Month & $2.00 \pm 0.00$ & $2.00 \pm 0.00$ & $2.00 \pm 0.00$ & 0.00 & 1.00 \\
\hline Supine & Muscle strength & $3.11 \pm 0.13$ & $3.08 \pm 0.03$ & $3.18 \pm 0.05$ & 1.37 & 0.29 \\
\hline Shoulder flexion & Month & $1.60 \pm 0.00$ & $1.60 \pm 0.00$ & $1.60 \pm 0.00$ & 0.00 & 1.00 \\
\hline Sitting & Muscle strength & $2.81 \pm 0.05$ & $2.87 \pm 0.08$ & $2.89 \pm 0.03$ & 2.30 & 0.15 \\
\hline Elbow extension & Month & $2.00 \pm 0.00$ & $2.00 \pm 0.00$ & $2.00 \pm 0.00$ & 0.00 & 1.00 \\
\hline Supine & Muscle strength & $3.40 \pm 0.08$ & $3.41 \pm 0.04$ & $3.44 \pm 0.03$ & 0.53 & 0.60 \\
\hline Elbow extension & Month & $1.90 \pm 0.00$ & $1.89 \pm 0.02$ & $1.89 \pm 0.03$ & 0.58 & 0.58 \\
\hline Prone & Muscle strength & $3.35 \pm 0.05$ & $3.35 \pm 0.04$ & $3.35 \pm 0.07$ & 0.00 & 1.00 \\
\hline Hip \& knee flexion & Month & $1.76 \pm 0.05$ & $1.77 \pm 0.03$ & $1.76 \pm 0.03$ & 0.09 & 0.92 \\
\hline Supine & Muscle strength & $2.87 \pm 0.16$ & $2.85 \pm 0.05$ & $2.84 \pm 0.03$ & 0.39 & 0.69 \\
\hline Hip \& knee flexion & Month & $2.82 \pm 0.04$ & $2.80 \pm 0.00$ & $2.80 \pm 0.00$ & 0.88 & 0.44 \\
\hline Prone & Muscle strength & $2.65 \pm 0.04$ & $2.71 \pm 0.04$ & $2.62 \pm 0.03$ & 8.73 & $0.01^{*}$ \\
\hline Hip \& knee extension & Month & $2.68 \pm 0.04$ & $2.70 \pm 0.00$ & $2.70 \pm 0.00$ & 0.88 & 0.44 \\
\hline Supported and independent standing & Muscle strength & $2.64 \pm 0.05$ & $2.62 \pm 0.04$ & $2.61 \pm 0.03$ & 0.47 & 0.64 \\
\hline
\end{tabular}

${ }^{*} p<0.05$. 
학적으로 유의한 차이가 없었다( $\mathrm{p}>0.05)$. 반면 5-9년 경력의 B 검사자 는 경부 굴곡의 근력평가 항목에서 1 차 검사와 2 차 검사에서 차이가
나타났으나 $(\mathrm{p}<0.05)$, 그 외의 나머지 항목에서는 통계학적으로 유의 한차이가 없었다 $(\mathrm{p}>0.05)$ (Table 4).

Table 4. Mean comparison of test-retest reliability of the K-PFMT

\begin{tabular}{|c|c|c|c|c|c|c|c|c|c|c|}
\hline \multirow{2}{*}{$\begin{array}{l}\text { Items } \\
\text { Position }\end{array}$} & & \multicolumn{3}{|c|}{$A$} & \multicolumn{3}{|c|}{$B$} & \multicolumn{3}{|c|}{ C } \\
\hline & & 1st & 2nd & $p$ & $1 \mathrm{st}$ & 2nd & $p$ & 1st & 2nd & $p$ \\
\hline Neck extension & M & $1.80 \pm 0.41$ & $1.80 \pm 0.41$ & 1.00 & $1.80 \pm 0.41$ & $1.80 \pm 0.41$ & 1.00 & $1.80 \pm 0.41$ & $1.80 \pm 0.41$ & 1.00 \\
\hline \multirow[t]{2}{*}{ Prone } & Rt & $2.80 \pm 0.83$ & $2.70 \pm 0.93$ & 0.16 & $2.70 \pm 0.80$ & $2.80 \pm 0.77$ & 0.16 & $2.95 \pm 0.83$ & $2.90 \pm 0.79$ & 0.33 \\
\hline & $\mathrm{Lt}$ & $2.80 \pm 0.83$ & $2.70 \pm 0.93$ & 0.16 & $2.70 \pm 0.80$ & $2.80 \pm 0.77$ & 0.16 & $2.95 \pm 0.83$ & $2.90 \pm 0.79$ & 0.33 \\
\hline Neck extension & $\mathrm{M}$ & $1.80 \pm 0.41$ & $1.80 \pm 0.41$ & 1.00 & $1.80 \pm 0.41$ & $1.80 \pm 0.41$ & 1.00 & $1.80 \pm 0.41$ & $1.80 \pm 0.41$ & 1.00 \\
\hline \multirow[t]{2}{*}{ Horizontal suspension } & Rt & $2.95 \pm 0.83$ & $2.90 \pm 0.85$ & 0.58 & $2.80 \pm 0.83$ & $2.75 \pm 0.79$ & 0.33 & $2.80 \pm 0.83$ & $2.85 \pm 0.89$ & 0.67 \\
\hline & Lt & $2.95 \pm 0.83$ & $2.90 \pm 0.85$ & 0.58 & $2.80 \pm 0.83$ & $2.75 \pm 0.79$ & 0.33 & $2.80 \pm 0.83$ & $2.85 \pm 0.89$ & 0.67 \\
\hline Neck flexion & $\mathrm{M}$ & $2.15 \pm 0.81$ & $2.10 \pm 0.85$ & 0.33 & $2.10 \pm 0.79$ & $2.10 \pm 0.85$ & 1.00 & $2.15 \pm 0.81$ & $2.10 \pm 0.19$ & 0.33 \\
\hline \multirow[t]{2}{*}{ Pull to sit/Supine } & $\mathrm{Rt}$ & $2.50 \pm 0.76$ & $2.50 \pm 0.76$ & 1.00 & $2.35 \pm 0.88$ & $2.55 \pm 0.76$ & $0.04^{*}$ & $2.40 \pm 0.82$ & $2.50 \pm 0.69$ & 0.33 \\
\hline & $\mathrm{Lt}$ & $2.50 \pm 0.76$ & $2.50 \pm 0.76$ & 1.00 & $2.35 \pm 0.88$ & $2.55 \pm 0.76$ & $0.04^{*}$ & $2.40 \pm 0.82$ & $2.50 \pm 0.69$ & 0.33 \\
\hline Trunk flexion (upper) & $\mathrm{M}$ & $2.10 \pm 0.79$ & $2.10 \pm 0.79$ & 1.00 & $2.05 \pm 0.76$ & $2.10 \pm 0.79$ & 0.33 & $2.10 \pm 0.79$ & $2.10 \pm 0.79$ & 1.00 \\
\hline \multirow[t]{2}{*}{ Pull to sit } & Rt & $2.60 \pm 0.75$ & $2.50 \pm 0.76$ & 0.16 & $2.25 \pm 0.85$ & $2.35 \pm 0.88$ & 0.16 & $2.30 \pm 0.80$ & $2.40 \pm 0.67$ & 0.16 \\
\hline & $\mathrm{Lt}$ & $2.60 \pm 0.75$ & $2.50 \pm 0.76$ & 0.16 & $2.25 \pm 0.85$ & $2.35 \pm 0.88$ & 0.16 & $2.30 \pm 0.80$ & $2.40 \pm 0.67$ & 0.16 \\
\hline Trunk flexion (lower) & $M$ & $2.20 \pm 0.95$ & $2.15 \pm 0.93$ & 0.58 & $2.10 \pm 0.97$ & $2.15 \pm 0.93$ & 0.33 & $2.20 \pm 0.95$ & $2.10 \pm 0.91$ & 0.16 \\
\hline \multirow[t]{2}{*}{ Supine } & $\mathrm{Rt}$ & $2.60 \pm 0.75$ & $2.60 \pm 0.82$ & 1.00 & $2.45 \pm 0.89$ & $2.50 \pm 0.83$ & 0.33 & $2.65 \pm 0.75$ & $2.60 \pm 0.82$ & 0.58 \\
\hline & $\mathrm{Lt}$ & $2.60 \pm 0.75$ & $2.60 \pm 0.82$ & 1.00 & $2.45 \pm 0.89$ & $2.50 \pm 0.83$ & 0.33 & $2.65 \pm 0.75$ & $2.60 \pm 0.82$ & 0.58 \\
\hline Trunk extension & $\mathrm{M}$ & $1.60 \pm 0.50$ & $1.60 \pm 0.50$ & 1.00 & $1.60 \pm 0.50$ & $1.65 \pm 0.49$ & 0.33 & $1.55 \pm 0.51$ & $1.60 \pm 0.50$ & 0.33 \\
\hline \multirow[t]{2}{*}{ Horizontal suspension } & Rt & $2.50 \pm 0.83$ & $2.45 \pm 0.94$ & 0.67 & $2.45 \pm 0.76$ & $2.40 \pm 0.76$ & 0.58 & $2.45 \pm 0.83$ & $2.45 \pm 0.76$ & 1.00 \\
\hline & $\mathrm{Lt}$ & $2.50 \pm 0.83$ & $2.45 \pm 0.94$ & 0.67 & $2.45 \pm 0.76$ & $2.40 \pm 0.76$ & 0.58 & $2.45 \pm 0.83$ & $2.45 \pm 0.76$ & 1.00 \\
\hline Trunk flexion \& extension & $M$ & $1.55 \pm 0.51$ & $1.55 \pm 051$ & 1.00 & $1.60 \pm 0.50$ & $1.60 \pm 0.50$ & 1.00 & $1.55 \pm 0.51$ & $1.55 \pm 0.51$ & 1.00 \\
\hline \multirow[t]{2}{*}{ Sitting } & $\mathrm{Rt}$ & $2.15 \pm 0.99$ & $2.20 \pm 1.01$ & 0.33 & $2.05 \pm 0.94$ & $2.15 \pm 0.99$ & 0.16 & $2.15 \pm 0.99$ & $2.15 \pm 0.99$ & 1.00 \\
\hline & $\mathrm{Lt}$ & $2.15 \pm 0.99$ & $2.20 \pm 1.01$ & 0.33 & $2.05 \pm 0.94$ & $2.15 \pm 0.99$ & 0.16 & $2.15 \pm 0.99$ & $2.15 \pm 0.99$ & 1.00 \\
\hline Trunk rotation & $M$ & $2.25 \pm 0.97$ & $2.25 \pm 0.97$ & 1.00 & $2.25 \pm 0.97$ & $2.25 \pm 0.97$ & 1.00 & $2.25 \pm 0.97$ & $2.20 \pm 0.95$ & 0.33 \\
\hline \multirow[t]{2}{*}{ Supine/Sitting } & $\mathrm{Rt}$ & $2.50 \pm 0.67$ & $2.65 \pm 0.59$ & 0.08 & $2.45 \pm 0.76$ & $2.40 \pm 0.75$ & 0.33 & $2.40 \pm 0.68$ & $2.35 \pm 0.67$ & 0.58 \\
\hline & $\mathrm{Lt}$ & $2.50 \pm 0.67$ & $2.65 \pm 0.59$ & 0.08 & $2.45 \pm 0.76$ & $2.40 \pm 0.75$ & 0.33 & $2.40 \pm 0.68$ & $2.35 \pm 0.67$ & 0.58 \\
\hline Shoulder flexion & $M$ & $1.60 \pm 0.50$ & $1.60 \pm 0.50$ & 1.00 & $1.60 \pm 0.50$ & $1.60 \pm 0.50$ & 1.00 & $1.60 \pm 0.50$ & $1.60 \pm 0.50$ & 1.00 \\
\hline \multirow[t]{2}{*}{ Sitting } & Rt & $2.50 \pm 0.95$ & $2.50 \pm 0.95$ & 1.00 & $2.60 \pm 0.99$ & $2.60 \pm 0.99$ & 1.00 & $2.70 \pm 1.08$ & $2.70 \pm 1.08$ & 1.00 \\
\hline & Lt & $2.50 \pm 0.95$ & $2.50 \pm 0.95$ & 1.00 & $2.60 \pm 0.99$ & $2.60 \pm 0.99$ & 1.00 & $2.70 \pm 1.08$ & $2.70 \pm 1.08$ & 1.00 \\
\hline Elbow extension & $M$ & $1.80 \pm 0.41$ & $1.80 \pm 0.41$ & 1.00 & $1.80 \pm 0.41$ & $1.80 \pm 0.41$ & 1.00 & $1.80 \pm 0.41$ & $1.80 \pm 0.41$ & 1.00 \\
\hline \multirow[t]{2}{*}{ Supine } & Rt & $3.20 \pm 1.06$ & $3.20 \pm 0.95$ & 1.00 & $3.20 \pm 1.06$ & $3.10 \pm 1.17$ & 0.16 & $3.25 \pm 0.97$ & $3.25 \pm 0.97$ & 1.00 \\
\hline & Lt & $3.20 \pm 1.06$ & $3.20 \pm 0.95$ & 1.00 & $3.20 \pm 1.06$ & $3.10 \pm 1.17$ & 0.16 & $3.25 \pm 0.97$ & $3.25 \pm 0.97$ & 1.00 \\
\hline Elbow extension & $M$ & $1.65 \pm 0.49$ & $1.65 \pm 0.49$ & 1.00 & $1.65 \pm 0.49$ & $1.65 \pm 0.49$ & 1.00 & $1.65 \pm 0.49$ & $1.65 \pm 0.49$ & 1.00 \\
\hline \multirow[t]{2}{*}{ Prone } & Rt & $3.20 \pm 1.05$ & $3.10 \pm 0.17$ & 0.16 & $3.10 \pm 1.12$ & $3.05 \pm 1.15$ & 0.33 & $3.20 \pm 1.06$ & $3.20 \pm 1.06$ & 1.00 \\
\hline & Lt & $3.20 \pm 1.05$ & $3.10 \pm 0.17$ & 0.16 & $3.10 \pm 1.12$ & $3.05 \pm 1.15$ & 0.33 & $3.20 \pm 1.06$ & $3.20 \pm 1.06$ & 1.00 \\
\hline Hip \& knee flexion & $\mathrm{M}$ & $1.65 \pm 0.49$ & $1.60 \pm 0.50$ & 0.33 & $1.65 \pm 0.49$ & $1.70 \pm 0.47$ & 0.33 & $1.70 \pm 0.47$ & $1.70 \pm 0.47$ & 1.00 \\
\hline \multirow[t]{2}{*}{ Supine } & Rt & $2.75 \pm 0.85$ & $2.65 \pm 0.93$ & 0.33 & $2.55 \pm 0.89$ & $2.55 \pm 0.83$ & 1.00 & $2.70 \pm 0.73$ & $2.60 \pm 0.88$ & 0.16 \\
\hline & $\mathrm{Lt}$ & $2.75 \pm 0.85$ & $2.65 \pm 0.93$ & 0.33 & $2.55 \pm 0.89$ & $2.55 \pm 0.83$ & 1.00 & $2.70 \pm 0.73$ & $2.60 \pm 0.88$ & 0.16 \\
\hline Hip \& knee flexion & $M$ & $2.85 \pm 1.93$ & $2.85 \pm 1.93$ & 1.00 & $2.95 \pm 1.85$ & $2.80 \pm 1.89$ & 0.33 & $2.90 \pm 1.89$ & $2.95 \pm 1.93$ & 0.33 \\
\hline \multirow[t]{2}{*}{ Prone } & Rt & $2.50 \pm 0.89$ & $2.50 \pm 0.89$ & 1.00 & $2.25 \pm 0.91$ & $2.10 \pm 0.88$ & 0.08 & $2.40 \pm 0.82$ & $2.35 \pm 0.88$ & 0.67 \\
\hline & $\mathrm{Lt}$ & $2.50 \pm 0.89$ & $2.50 \pm 0.89$ & 1.00 & $2.25 \pm 0.91$ & $2.10 \pm 0.88$ & 0.08 & $2.40 \pm 0.82$ & $2.35 \pm 0.88$ & 0.67 \\
\hline Hip \& knee extension & $\mathrm{M}$ & $2.50 \pm 1.15$ & $2.45 \pm 1.15$ & 0.33 & $2.60 \pm 1.05$ & $2.60 \pm 1.05$ & 1.00 & $2.60 \pm 1.05$ & $2.60 \pm 1.05$ & 1.00 \\
\hline \multirow[t]{2}{*}{ Supported and independent standing } & Rt & $2.55 \pm 0.83$ & $2.55 \pm 0.89$ & 1.00 & $2.35 \pm 0.88$ & $2.50 \pm 0.83$ & 0.08 & $2.65 \pm 0.81$ & $2.55 \pm 0.89$ & 0.16 \\
\hline & Lt & $2.55 \pm 0.83$ & $2.55 \pm 0.89$ & 1.00 & $2.35 \pm 0.88$ & $2.50 \pm 0.83$ & 0.08 & $2.65 \pm 0.81$ & $2.55 \pm 0.89$ & 0.16 \\
\hline
\end{tabular}

K-PFMT: Korean pediatric functional muscle testing, M: Month score, Rt: Muscle strength score of right side, Lt: Muscle strength score of left side. " $p<0.05$. 
Table 5. Pearson correlation coefficient between the K-PFMT and GMFM

\begin{tabular}{|c|c|c|c|c|}
\hline Items & Position & $C P(n=20)$ & $\mathrm{DD}(\mathrm{n}=20)$ & Total $(n=40)$ \\
\hline Neck extension & Prone & $0.92^{*}$ & $0.61^{*}$ & $0.82^{*}$ \\
\hline Neck extension & Horizontal suspension & $0.86^{*}$ & $0.64^{*}$ & $0.79^{*}$ \\
\hline Neck flexion & Pull to sit/Supine & $0.91^{\star}$ & $0.79^{*}$ & $0.87^{\star}$ \\
\hline Trunk flexion (upper) & Pull to sit & $0.82^{*}$ & $0.77^{\star}$ & $0.81^{*}$ \\
\hline Trunk flexion (lower) & Supine & $0.88^{*}$ & $0.83^{*}$ & $0.84^{*}$ \\
\hline Trunk flexion (lower) & Horizontal suspension & $0.74^{*}$ & $0.56^{*}$ & $0.67^{*}$ \\
\hline Trunk flexion \& extension & Sitting & $0.93^{*}$ & $0.91^{*}$ & $0.90^{*}$ \\
\hline Trunk rotation & Supine/Sitting & $0.97^{*}$ & $0.90^{*}$ & $0.84^{*}$ \\
\hline Shoulder flexion & Supine & $0.91^{*}$ & $0.75^{\star}$ & $0.80^{*}$ \\
\hline Shoulder flexion & Sitting & $0.93^{*}$ & $0.87^{\star}$ & $0.80^{*}$ \\
\hline Elbow extension & Supine & $0.93^{*}$ & $0.69^{*}$ & $0.82^{*}$ \\
\hline Elbow extension & Prone & $0.94^{*}$ & $0.65^{\star}$ & $0.84^{*}$ \\
\hline Hip \& knee flexion & Supine & $0.94^{*}$ & $0.75^{*}$ & $0.85^{*}$ \\
\hline Hip \& knee flexion & Prone & $0.92^{*}$ & $0.92^{*}$ & $0.91^{*}$ \\
\hline Hip \& knee extension & Supported and independent standing & $0.97^{*}$ & $0.84^{*}$ & $0.91^{\star}$ \\
\hline Total (15 items) & & $0.98^{*}$ & $0.92^{*}$ & $0.96^{*}$ \\
\hline
\end{tabular}

K-PFMT: Korean pediatric functional muscle testing, GMFM: Gross motor function measure, DD: Developmental delay, CP: Cerebral palsy. ${ }^{*} \mathrm{p}<0.05$.

\section{5. 한국형 소아 기능근력검사의 공인타당도 검증 결과}

한국형 소아 기능근력검사의 공인타당도 분석을 위하여 재설정된 15 개 항목 각각의 등급 점수와 GMFM-66의 총점, 재설정된 15 개 항 목의 총점수와 GMFM-66의 총점과의 Pearson 상관 계수를 분석한 결과, 뇌성마비 아동군에서는 0.74 에서 0.98 로 모두 높은 상관관계를 보였으며, 발달지연 아동군에서는 0.56 에서 0.92 로 뇌성마비 아동군 보다는 낮지만 비교적 높은 상관관계를 보였다. 뇌성마비 아동군 20 명과 발달지연 아동군 20 명, 총 40 명의 상관 계수 분석 결과는 0.67 에 서 0.96 으로 높은 상관 관계를 보였다(Table 5).

\section{고 찰}

신뢰도 검증을 위해 사용되는 내적 일치도 검사는 평가지를 이용하 여 평가도구에서 한 항목과 다른 항목과의 관련성을 비교하여 그 항 목의 신뢰도를 비교하는 것으로 최근 연구에서는 크론바 알파 값이 많이 이용된다.11-14 내적 일치도 계수가 높으려면 문항 사이의 상호 관 련성이 높아야하며, 이를 위해서는 평가도구가 한 가지 특성 혹은 능 력만을 측정하는 동질적인 검사여야 한다. 따라서 각 문항이 같은 난 이도로 구성된 평가도구이면 높은 신뢰도가 나올 수 있다. ${ }^{11}$ Nunnally 와 Berstein ${ }^{15}$ 은 내적 일치도의 판단 기준에 의하면 0.70 이상이면 받 아들이기에 적합한 수준(acceptable reliability)이며, 0.80 이상이면 좋 은 신뢰도(good reliability), 0.90 은 받아들일 수 있는 최대값이라고 제 시했다. ${ }^{2}$ 본 연구에서 개발된 한국형 소아 기능근력검사의 내적 일치 도를 검증한 결과, 15 문항 각각의 크론바 알파 값은 0.98 에서 0.99 로
매우 높았으며, 15 개 문항 전체의 크론바 알파 값 역시 0.98 로 매우 높 은 수치로 한국형 소아 기능근력검사가 문항 간 상호관련성이 매우 높은항목으로 구성된 검사임을 알수 있었다.

검사자간 신뢰도는 동일한 집단을 대상으로 다른 검사자들이 검 사를 시행할 때 검사 점수의 일관성이 보이는지를 알아보기 위해 사 용된다. 이런 검사자간 신뢰도에서는 검사자의 판단이 검사를 시행 하는데 가장 중요하다고 하였다. ${ }^{3}$ 이에 본 연구에서 개발한 한국형 소 아 기능근력검사가 경력 차이에 따라 검사자간 신뢰도를 검증하고 자 2-4년, 5-9년, 10년 이상의 세 군으로 나누어 평가 결과에 대한 급간 내 상관계수를 구한 결과, 뇌성마비 아동군의 각 항목의 개월평가에 서는 경력 차이에 따른 세 군 모두에서 0.89 이상으로 검사자간 신뢰 도가 높은 것으로 확인되었다. 각 항목의 근력평가에서는 5-9년 경력 의 검사자군은 0.81 이상, 10 년 이상의 검사자군은 0.82 이상, 14 명 전 체의 경우 0.77 이상으로 높은 신뢰도를 보였으나, 2-4년 경력의 검사 자에서 체간 신전 항목에서만 0.65 로 낮은 신뢰도를 보이고, 나머지 14 개 항목에서는 높은 신뢰도를 보였다.

반면 발달지연 아동군의 개월평가는 2-4년 경력, 10 년 이상의 검사 자는 각각 0.75 이상, 0.88 이상으로 높은 신뢰도를 보였으나, 5-9년 경 력의 검사자군에서 경부신전의 엎드린 자세 항목에서만 0.71 로 약간 낮은 신뢰도를 보였으나 나머지 14항목은 모두 높은 신뢰도를 보였 다. 각 항목의 근력평가에서는 10 년 이상의 검사자군에서만 0.87 이상 으로 높은 신뢰도를 보였고, 2-4년 경력의 검사자군과 5-9년 경력의 검사자군에서는 각각 7 개의 항목에서 0.75 미만의 낮은 신뢰도를 보 였다. 
또한, 경력 차이에 따른 검사자간 신뢰도를 비교하기 위하여 일원 배치분석으로 비교한 결과, 뇌성마비 아동군의 개월평가에서는 경 부 신전의 엎드린 자세 항목과 하부 체간 굴곡 항목의 2 개 항목에서 만 검사자군 간 차이가 있었고, 각 항목의 근력평가에서는 경부신전 의 엎드린 자세 항목, 하부 체간 굴곡 항목, 견관절 굴곡의 바로 누운 자세 항목의 3 개 항목에서 검사자군 간 차이가 있었다. 발달지연 아 동군의 개월평가는 하부 체간 굴곡과 체간 신전의 2 개 항목에서 검 사자군 간 차이가 있었으며, 각 항목의 근력평가에서는 경부 굴곡과 고관절과 슬관절 굴곡의 엎드린 자세의 2 개 항목에서 검사자군 간 차이가 있었다.

이러한 결과를 통해 본 연구자가 시행한 사전 연구 ${ }^{14}$ 에서 드러난 문제점 중 하나였던 불명확한 개월 간의 차이의 기준이 본 연구를 통 해 평가 문항이 수정 및 보완되어 개월 간의 차이의 기준이 보다 명확 하게 제시되었기 때문에 뇌성마비 아동군과 발달지연 아동군, 두 군 모두의 개월평가에서 2-4년, 5-9년, 10년 이상의 검사자 간 높은 신뢰 도를 보였다고 사료된다.

이와는 달리, 각 항목의 근력평가의 검사자 간 신뢰도를 살펴보면, 10 년 이상 경력의 검사자군에는 모두 높은 신뢰도를 보인 반면, 2-4 년, 5-9년 경력의 검사자의 경우, 뇌성마비 아동군에서는 비교적 높은 신뢰도를 보였으나, 발달지연 아동군에서는 총 15 평가 항목 중에 7 개 의 항목에서 낮은 검사자간 신뢰도를 보였다. 이것은 검사에 참여한 검사자들의 풍부한 임상적인 경험과 평가도구를 얼마나 잘 숙달하 게 사용할 수 있느냐에 대한 문제도 신뢰도에 많은 영향을 미친다고 한 선행연구와ㄱㅏㅏㅌㅇㅣ 임상적 경험의 차이로 인한 것으로 사료된다.

또한 본 연구에서는 검사시 아동에서 나타날 수 있는 변수를 줄이 기 위해 비디오 화면을 보면서 평가하도록 하였으나, 수행 시의 아동 의 자세와 움직임이 카메라의 각도에 따라서 다르게 보일 수 있기 때 문에 측정 오차가 생길 수 있다는 선행연구 ${ }^{3,13,14}$ 와 같이, 검사 시 제공 되는 저항강도의 정도나 자세나 움직임의 3 차원적 관찰에 제한으로 인하여 이와 같은 결과가 도출되었을 것으로 사료된다. 따라서 아동 을 직접 평가하는 것이 더 바람직하다고 한 선행 연구 ${ }^{16}$ 의 주장처럼 임상에서 직접 아동을 평가한다면 보다 높은 검사자 간 신뢰도를 볼 수 있을 것으로 생각된다.

검사자 간 신뢰도를 높이기 위해서는 검사시행 과정과 채점 과정, 표준점수 산출 과정을 검사 매뉴얼을 통해 숙지해야만 하고 연구를 설계한 사람은 검사자들에게 검사 시행 방법과 객관적으로 채점할 수 있도록 자세한 설명을 해주며 비디오 훈련을 통하여 검사 규준에 일치하여 정확하게 판단할 수 있도록 도와주어야 한다. 본 연구에서 는 한국형 소아 기능근력검사를 숙지할 수 있도록 3 일 이상을 훈련하 고 비디오 훈련도 시행하였으나, 본 연구에서 개발된 한국형 소아 기 능근력검사가 생후 1 년 동안의 운동발달을 바탕으로 구성되어 있어
서 임상 경험이 아주 많은 10 년 이상의 경력의 검사자에게는 본 연구 자가 제안한 기간에도 습득이 가능하였을 것으로 생각되나, 나머지 경력의 검사자에게 좀 더 많은 기간이 주어진다면 보다 높은 검사자 간 신뢰도를 보일 것으로 사료된다.

검사-재검사 신뢰도 분석을 위하여 급간 내 상관계수를 분석한 결 과, 2-4년 경력, 5-9년 경력, 10 년 이상의 경력의 3 명의 검사자 모두에서 각 항목의 개월평가에서 0.89 이상으로 분포하였으며, 각 항목의 근력 평가는 0.82 이상으로 분포하였다. 일반적으로 급간 내 상관계수가 0.75 이상이면 높은 신뢰도를 나타낸다는 문헌17을 바탕으로, 본 연구 를 통해 한국형 소아 기능근력검사의 검사-재검사의 신뢰도가 높다 는 것을 알수 있었다.

경력 차이에 따라 1 차 검사와 2 차 검사의 평가 점수의 차이를 알아 보기 Paired t-test를 분석한 결과, 5-9년 경력의 검사자의 경부 굴곡의 근력평가 항목에서만 1 차 검사와 2 차 검사에서 차이가 나타났으며, 그 외의 나머지 항목에서는 통계학적으로 유의한 차이가 없었다. 이 와 같은 결과로 임상 경력 차이는 본 연구에서 개발한 한국형 소아 기능근력검사의 검사-재검사에는 큰 영향을 미치지 않는 것으로 사 료된다.

Seong ${ }^{18}$ 는 신뢰도에 영향을 주는 요인으로써 적은 문항수, 문항의 난이도 적절성, 문항의 변별도, 측정 내용의 범위, 충분한 검사 시간 중 5 가지를 제시하였는데, 본 연구 결과를 고려해 볼 때 개발된 한국 형 소아 기능근력검사는 적절한 문항 수 및 난이도, 높은 변별도, 적 합한 측정 내용으로 구성된 것으로 사료된다.

공인타당도는 측정도구의 값과 동일 시점의 기준 값과의 관련성의 정도 또는 이미 타당성이 입증된 측정도구에서 측정한 점수와의 관 련성의 정도를 표현하는 타당도이다. ${ }^{19-21}$ 기존의 도수근력검사의 공 인타당도를 위해 사용된 측정도구는 성인의 경우, 소형역량계(handheld dynamometer)나 약력계(myometer)와 같은 기구를 이용하거나 근전도를 이용하였고, ${ }^{22}$ 소아의 경우 소형약력계를 이용한 연구들은 있으나, 4 세 이하의 어린이에게 약력계를 사용한 과거 문헌은 없었다 고 하였다.23

본 연구에서 개발한 한국형 소아 기능근력검사는 5 세 미만의 운 동발달에 문제가 있는 아동 특히, 의사소통이 어려운 아동을 대상으 로 근력평가를 위해 고안되었기 때문에 기존의 선행연구와 같이 소 형약력계나 기타 기구를 이용하여 공인타당도 분석을 하는 것은 불 가능하였다. 한국형 소아 기능근력검사는 생후 1년 동안 볼 수 있는 아동의 중력에 대한 기능적 움직임을 관찰하여 근육군에 대한 근력 평가를 하도록 고안되었기 때문에, 공인타당도 분석을 위하여 아동 의 기능평가를 위해 가장 많이 사용되고 있는 GMFM-66과의 상관관 계를 알아보고자 하였다. GMFM-66의 총점과의 Pearson 상관계수를 분석한 결과, 뇌성마비 아동군에서는 0.74 에서 0.98 로 모두 높은 상관 
관계를 보였으며, 발달지연 아동군에서는 0.56 에서 0.92 로 뇌성마비 아동군보다는 낮지만 비교적 높은 상관관계를 보였다. 뇌성마비 아 동군 20 명과 발달지연 아동군 20 명, 총 40 명을 상관 계수 분석의 결과 는 0.67에서 0.96으로 GMFM-66과 높은 상관 관계를 가지고 있는 것 으로 나타났다. 이 결과는 본 연구에서 개발된 한국형 소아 기능근력 검사가 5 세 미만의 아동의 기능근력검사를 하는데 매우 유용한 도구 임을 입증하는 결과라 할 수 있다. 또한 GMFM의 경우 아동이 항목 을 어떻게 잘 행하는가 보다는 얼마나 많이 완수하는가를 평가하며, 서로 다른 수준의 운동기능을 보임에도 불구하고 동일한 점수를 보 일 수 있는 등의 측정상의 제한점이 있다. ${ }^{12}$ 이와는 달리, 본 연구에서 개발된 한국형 소아 기능근력검사는 기능적 움직임의 반응과 자발 적 움직임을 개월평가와 등급에 따른 근력평가로 나누어져 좀 더 질 적인 평가가 가능할 뿐만 아니라, 총점으로 평가하는 GMFM과는 달 리 기능에 따른 현재 개월 수준을 평가할 수 있으며 각 개월에서의 근 력정도를 기존의 6 등급 도구로 사용하여 누구나 아동의 상황을 쉽 게 평가하고 파악할 수 있으므로, 아동의 기능 및 근력을 평가하기 위 한 임상적 도구로 유용하게 사용될 것으로 사료된다.

본 연구에서 주목할 점은 뇌성마비에 비해 발달지연 아동에서 몇 항목에서 낮은 신뢰도와 타당도의 분석 결과가 나타난 점이다. 특히 경부 굴곡과 경부 신전, 체간 굴곡과 체간 신전 및 체간 회전, 즉 근위 부의 기능근력평가 항목에서 낮은 신뢰도와 타당도를 보였다. 이는 발달지연 아동의 경우 근육의 저긴장으로 체간, 머리, 목을 유지하는 데 어려움이 있어, 자세 조절에 문제가 야기된다는 선행연구 ${ }^{24}$ 와 같 이 경부와 체간의 기능근력평가는 비교적 낮게 평가되었으나, 대동 작 기능 평가에서는 비교적 높은 것으로 나타나 낮은 신뢰도와 타당 도를 보인 것으로 사료된다. 또한 연구대상자의 특성 중 대동작 기능 분류 체계를 살펴보면, 2,3 단계에 해당하는 중간 수준의 대동작 기 능을 가진 발달지연 아동의 수가 전체의 $75 \%$ 를 차지하고 있어 한국 형 소아 기능근력검사 시 근력 등급을 평가하는 데 어려움이 있었을 것으로 사료된다.

이와는 달리 비정상적인 긴장도를 특징으로 하는 뇌성마비의 경 우 비정상적인 긴장도가 기능근력평가에 큰 영향을 줄 것이라는 예 상과는 달리 뇌성마비 아동의 경우 높은 신뢰도와 타당도의 결과가 나타났는데, 이는 본 연구에 참여한 뇌성마비 아동의 대동작 기능 분 류 체계를 살펴보면, 1-2단계로 기능이 좋은 아동이 $50 \%$ 를 차지하였 으며, 기능이 심하게 좋지 않은 5 단계의 아동이 $24 \%$ 를 차지하고 있어 아동의 대동작 기능 차이가 극명하여 한국형 소아 기능근력검사 시 근력 등급을 평가하는데 발달지연 아동에 비해 보다 용이하였을 것 으로 사료된다.

결론적으로 본 연구에서 시행된 한국형 소아 기능근력검사의 신 뢰도와 타당도 분석의 결과를 바탕으로 한국형 소아 기능근력검사
는 발달지연 아동뿐만 아니라 뇌성마비 아동에게도 신뢰도와 타당 도가 높은 검사도구라는 것이 입증되었다. 소아 물리치료사들이 한 국형 소아 기능근력검사를 사용하여 보다 객관적이고 정확한 평가 를 할 수 있을 것으로 사료되며, 이를 바탕으로 의사소통이 원활하지 않는 5 세 미만의 운동 발달에 문제가 있는 아동의 근력 상태를 정확 히 파악하여, 치료목표 및 계획의 설정에 용이하게 해주므로 전반적 인 소아 물리치료의 질을 향상시킬 수 있을 것으로 사료된다. 따라서 본 연구는 국내의 운동발달에 문제가 있는 아동들의 근력을 평가하 는 검사 도구로써 임상에서 매우 유용하게 사용될 수 있는 최초의 소 아 기능근력검사인 한국형 소아 기능근력검사를 한국 실정에 맞도 록수정 및 보완하여 개발하였고, 그 신뢰도와 타당도의 유효성을 입 증했다는 것에 큰 의의가 있다.

본 연구의 제한점으로는 첫째, 본 연구의 연구대상 아동의 표집이 경기도 지역 특정 병원을 내원하는 40 명의 아동으로 폭넓게 이루어 지지 않았으며, 연구대상자의 표집수가 너무 작아서 국내의 모든 아 동을 대상으로 일반화하는데 어려움이 있다. 둘째, 본 연구의 한국형 소아 기능근력검사를 평가한 검사자 또한 경기도 지역 특정 병원으 로 제한적이어서 검사의 신뢰도를 일반화하는데 어려움이 있을 것으 로 생각된다. 마지막으로 본 연구에서는 공인타당도만을 검증하였는 데, 앞으로의 연구에서는 구성타당도나 예측타당도의 추가적인 타당 도 검증이 이루어져야 할 것이며, 국내 다양한 지역의 아동들에게 적 용하여 일반화 할 수 있는 자료 수집이 필요할 것으로 사료된다.

\section{ACKNOWLEDGEMENTS}

본 저자의2016년 대구가톨릭대학교 박사학위 논문의 데이터를 일부 인용함.

\section{REFERENCES}

1. Lee MR. The analysis of reliability and validity of K-BSID-II. UISan University. Dissertation of Master's Degree. 2005.

2. Park HJ, Yi CH, Cho SH et al. Physical therapist's understanding and the usage of assessment tools for children with delayed development and cerebral palsy. KAUTPT. 2000;7(1):1-21.

3. Kim CK. Reliability of gross motor scale of the Peabody Developmental Motor Scales-2. YongIn University. Dissertation of Master's Degree. 2003.

4. Kim JS. Comparison of GMFM and BSID-II for infants with developmental delays. YongIn University. Dissertation of Master's Degree. 2002.

5. Venita LC. Techniques of pediatric muscle testing: Muscle and sensory testing. 2nd ed. Korea. Koonja Publishing Inc. 2006.

6. Seo HJ. Reliability and validity of the new Korean version of pediatric functional muscle testing. Doctor's Degree. Catholic University of Daegu. 2016. 
7. Ko JY, Kim KW. Test-retest, inter-rater, and intra-rater reliability of a pediatric balance scale in children with cerebral palsy. J Kor Phys Ther. 2010;22(4):43-8.

8. Kim GW, Ko JY, Baek SG. The reliability of a pediatric balance scale based on the raters' cilinical work experience and test experience. J Kor Phys Ther. 2010;22(6):35-45.

9. Park EY, Kim WH. Relationship between function classification systems and the pedi functional skills in children with cerebral palsy. Physical Therapy Korea. 2014;21(3):55-62.

10. Escolar DM, Henricson EK, Mayhew J et al. Clinical evaluator reliability for quantitative and manual muscle testing measures of strength in children. Muscle Nerve. 2001;24(6):787-93.

11. Lee SH. Development, reliability, and validity of the Korean activity card sort. Yunsei University. Dissertation of Doctorate Degree. 2009.

12. Park EY, Park SY. Comparison of reliability and validity between GMFM-88 and GMFM-66 in children with cerebral palsy. Physical Therapy Korea. 2010;17(3):40-7.

13. Seo HJ, Kim JH. The reliability of the pediatric functional muscle testing in children with developmental delay. J Kor Phys Ther. 2015;25(4):1839.

14. Park JY, Cho SH. The reliability and validity of Korean version of the wheelchair user's shoulder pain index in wheelchair users. J Korean Soc Phys Med. 2013;8(4):573-82.
15. Nunnally JC, Bernstein IH. Psychometric theory. New York, McGrawHill Inc., 1994.

16. Gowland C, Boyce WF, Wright V et al. Reliability of the gross motor performance measure. Phys Ther. 1995;75(7):597-602.

17. Lee CH. Research Methodology. Seoul, Gyechuk Munwhasa, 2007.

18. Seong TJ. Validity and reliability. Korea, Hakjisa corp., 2002.

19. An NY. Assistive technology assessment tool development and examination. Korea Nazarene University. Dissertation of Doctorate Degree. 2013.

20. An SH, Lee JH. Reliability and validity of Korean version of the functional movement screen. J Kor Phys Ther. 2010;22(5):83-93.

21. Kim JH, Park JW. Concurrent validity between figure-of-8 walking test and functional tests included tasks for dynamic balance and walking in patient with stroke. J Kor Phys Ther. 2012;24(5):325-33.

22. Scott CC, George JG. On the reliability and validity of manual muscle testing: a literature review. Chiropr Osteopat. 2007;15(4):1-23.

23. Sloan C. Review of the reliability and validity of myometry with children. Phys Occup Ther Pediatr. 2002;22(2):79-92.

24. Park HS, Lee NH, Kim KM et al. The effects of proprioceptive-vestibular based sensory integration intervention on drooling and postural control of the child with developmental delay. Journal of Special Education \& Rehabilitation Science. 2013;52(1):337-54. 